AGRARIS: Journal of Agribusiness and Rural Development Research

Vol. 6 No. 2: July-December 2020

Article History:

Submitted: March 31 st 2020

Accepted: November $12^{\text {th }}, 2020$
Yan Eka Dharmawan*, Endang Siti Rahayu, Minar Ferichani

Sebelas Maret University

*)Correspondence email: yanekadharmawan84@gmail.com

\title{
The Supply Chain Efficiency of Tilapia Farming in Floating Net Cage (FNC) in Wonogiri Regency
}

DOI: https://doi.org/10.18196/agr.62101

\begin{abstract}
This study aims to determine the supply chain mechanism and analyze the supply chain efficiency of tilapia farming in floating net cage (FNC) in Wonogiri Regency. This research utilized the Data Envelopment Analysis (DEA) as the method. The research was conducted in Wonogiri and Wuryantoro Districts as the center of tilapia farming and other districts as marketing objectives. The research sample consisted of 50 tilapia farmers, 14 wholesalers, and 6 retailers. The data were collected using the snowball sampling method. The research used questionnaires and in-depth interviews. The results revealed that the structure of tilapia supply chain actors in Wonogiri Regency consisted of farmers, wholesalers, and retailers. As much as $35.71 \%$ of tilapia farmers chose to sell their products to wholesalers, $64.29 \%$ to retailers, and none sold directly to consumers. Based on performance measurement using the DEA method, the most efficient actors in the tilapia supply chain in Wonogiri Regency were wholesalers, with an average efficiency value of 0.998 , followed by retailers with an average efficiency value of 0.982 , and the most inefficient actors were farmers, with an average efficiency value of 0.789 .
\end{abstract}

Keywords: Data Envelopment Analysis, efficiency, supply chain, tilapia

\section{INTRODUCTION}

The potential fishery land in Indonesia is estimated at 17.74 million hectares, consisting of 2.23 million hectares of freshwater aquaculture, 2.96 million hectares of brackish water aquaculture, and 12.55 million hectares of marine aquaculture. However, farmed land utilization has only reached $16.62 \%$ for freshwater aquaculture, $50.06 \%$ for brackish water aquaculture, and 2.09\% for marine aquaculture. During the 2011-2017 period, aquaculture production has increased significantly, from 7.93 million tons in 2011 to 17.22 million tons in 2017. Accordingly, the production value has increased by around $22.51 \%$ per year in the same period (Directorate General of Strengthening the Competitiveness of Marine and Fishery Products, 2018).

The Central Bureau of Statistics noted that the aquaculture sub-sector has a great opportunity to contribute to Indonesia's Gross Domestic Product (GDP). Fishery GDP growth has increased from year to year. During the 2016-2019 period, the GDP growth in the fishery sector was higher than the agricultural sector, with an average of 5.56 for fishery and 3.54 for the agricultural sector. One of the achievements of the fishery sector's 
contribution to national GDP comes from aquaculture activities. Thus, it must be considered in the national economy (Central Statistics Agency, 2020).

Central Java GDP at Current Price According to Business Fields in the fishery sector amounted to 6.22 trillion rupiahs in 2010 and reached 12.24 trillion rupiahs in 2017; these data indicate a significant increase (Central Java of Central Statistics Agency, 2018). According to Kohar and Wibowo (2015), the economic growth of the fishery sector continuing to increase in Central Java Province and the increase in demand for fish in the future will encourage efforts to improve the quality of fishery products to compete in the global market through (1) the efficiency of production costs, (2) improving product quality to be accepted by the market, and (3) a wider marketing network.

Wonogiri Regency is a producer of floating net cage (FNC) fish, placing in third place in 2016 in Central Java Province, with a production of 6,343.26 tons (DKP of Central Java Province, 2017). Tilapia is farmed in the KJA in the Gajah Mungkur Reservoir. However, the production and marketing processes face several obstacles.

The inefficient supply chain of tilapia in Wonogiri Regency, due to the not optimal application of farming technology by farmers, inefficient fish traders in conducting their business, fluctuations in tilapia prices due to product availability and unstable consumer demand, availability of tilapia products at the farmer level will affect the flow of goods, money, and information between farmers, wholesalers, and retailers, which in turn will affect supply chain efficiency. According to Indrajit and Djokopranoto (2002), supply chain actors cooperate to deliver products on time, in the right quantity, and product quality adjusted to the demand of the end consumers. Tilapia products marketed in fresh and live are perishable, thus having a high potential for risk of loss in every stage of the supply chain (Setiadi et al., 2018). This study aims to determine the supply chain mechanism of tilapia farming in Wonogiri Regency and analyze the efficiency of the supply chain.

\section{RESEARCH METHOD}

This research employed the descriptive analysis as the basic method. This method examines the status of human groups, an object, a condition, a thought, or an event in the present, aiming to create a systematic, factual, and accurate picture of the facts, properties, and relationships between the investigated phenomena (Nazir, 2014). Surakhmad (1994) stated that descriptive research focuses on solving actual problems in the present. The actual problems observed in this research on the supply chain of tilapia farming in Wonogiri Regency were regarding the supply chain management mechanism and its performance.

The research location was determined purposively in Wonogiri Regency, specifically in Wonogiri and Wuryantoro Districts as the center of tilapia farming in FNC and related districts as marketing locations. This study used both primary and secondary data. Primary data were obtained through interviews and questionnaires to analyze: (1) the tilapia supply chain mechanism, 2) the performance of each supply chain actor (3) efforts that can be applied to produce an efficient tilapia supply chain. On the other hand, secondary data were obtained from the presentation of related agency data functioned as a compliment. 
Respondents comprised 50 tilapia farmers in Wonogiri and Wuryantoro Districts, 6 wholesalers, and 14 retailers in several districts. Furthermore, interviews were conducted with farmers, wholesalers, and retailers, using the snowball sampling method. According to Suratna et al. (1995), snowball is a sampling method with small groups asked to show their respective friends. Then the friends were asked to show their friends, and so on. Thus, it is expected that the supply chain flow of tilapia from producers to consumers can be identified.

This research utilized the descriptive analysis method. After knowing the description of the tilapia supply chain, supply chain actors were analyzed using the Data Envelopment Analysis (DEA) method to determine the performance of each actor to improve the performance efficiency assisted by DEAP 2.1 software.

\section{RESULT AND DISCUSSIONS}

\section{Tilapia supply chain mechanism}

Several actors from farmers, wholesalers, and retailers formed the supply chain mechanism for tilapia farming in Wonogiri Regency. Pujawan (2005) suggested three distribution patterns that must be managed in the supply chain, the flow of goods, money (financial), and information. The distribution pattern of goods flows from upstream to downstream, money flows in reverse from downstream to upstream, while information flows from upstream to downstream and vice versa.

The supply chain emphasizes more on the series of the flow of materials and information, while supply chain management highlights efforts to integrate supply chain collections. At the agroindustrial level, supply chain management pays attention to supply, stock, and transportation distribution (Vorst, 2004).

The supply chain channel of tilapia farming in Wonogiri Regency is displayed in the following figure.

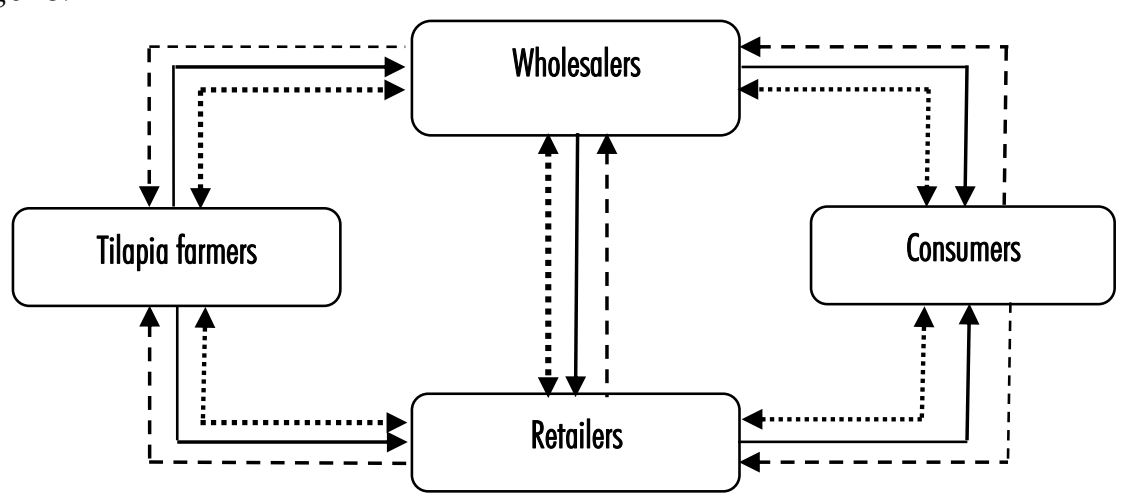

Information:

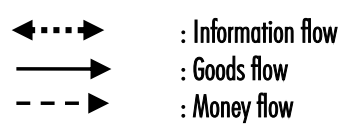

FIGURE 1. TILAPIA SUPPIY CHAIN CHANNEL IN WONOGIRI REGENCY 
1. Supply chain channel

There are three types of flows managed, namely:

a. The flow of goods from producers to consumers through wholesalers and retailers

b. Money flows from consumers to traders and from traders to producers

c. The flow of information moving in two directions along the chain, either from producers to traders to consumers or vice versa

Data accuracy is essential in the supply chain channel, determining the accuracy of information and materials or products. An adequate supply chain is inseparable from the management regulating it to be proper. Supply chain management takes a systems approach to view the supply chain as a single entity (Pujawan, 2005). Janvier (2012) stated that in principle, the role of the supply chain is to add value to products by moving them from one location to another or by carrying out a process of change to them. Adding value to the supply chain can be carried out on quality, delivery costs, or applied to flexibility during delivery and innovation (Trienekens, 2011).

\section{Supply chain actors}

a. Actor 1: Tilapia farmers

Tilapia farmers are the first supply chain actors. They are the producers of tilapia by carrying out the farming process from preparing the farming site, spreading seeds, providing food, maintaining water quality, preventing and controlling fish pests, harvesting to marketing.

b. Actor 2: Wholesalers

As the second supply chain actors, wholesalers are directly related to farmers as producers of tilapia. They take tilapia from farmers and distribute it to retailers and consumers directly as the next supply chain actors.

c. Actor 3: Retailers

As the third supply chain actor, retailers obtain goods from farmers or wholesalers and distribute them directly to consumers.

\section{Measurement of Supply Chain Efficiency}

Analysis of the supply chain efficiency of tilapia farming in Wonogiri Regency used the Data Envelopment Analysis (DEA) approach. Supply chain efficiency measurement was carried out by comparing one actor to another within the supply chain. Each performance attribute had a performance indicator useful for determining the performance efficiency of a supply chain. This method aims to allocate appropriate resources (Coelli, 1996). The performance measurement through the DEA approach involved attributes consisting of input and output variables. According to Zhou et al. (2008), DEA makes it possible to identify which units are efficient and which are inefficient to improve them to be efficient.

1. Analysis of Tilapia Supply Chain Efficiency at the Farmer Level

The performance measurement of tilapia farmers involved 50 samples in two districts. The results of data processing illustrate the results of measuring the efficiency of tilapia farmers based on the DEAP 2.1 program, presented as follows: 
TABLE 1. DISTRIBUTION OF DMU BASED ON THE EFFICIENCY LEVEL OF TILAPIA FARMING IN WONOGIRI REGENCY

\begin{tabular}{ccr}
\hline Efficiency Value & Number of DMU (Person) & Percentage (\%) \\
\hline $0 \leq x<0.1$ & 0 & 0.00 \\
$0.1 \leq x<0.2$ & 0 & 0.00 \\
$0.2 \leq x<0.3$ & 0 & 0.00 \\
$0.3 \leq x<0.4$ & 0 & 0.00 \\
$0.4 \leq x<0.5$ & 0 & 0.00 \\
$0.5 \leq x<0.6$ & 3 & 6.00 \\
$0.6 \leq x<0.7$ & 16 & 32.00 \\
$0.7 \leq x<0.8$ & 8 & 16.00 \\
$0.8 \leq x<0.9$ & 6 & 12.00 \\
$0.9 \leq x<1.0$ & 5 & 10.00 \\
1 & 12 & 24.00 \\
\hline Total & 50 & 100.00 \\
\hline
\end{tabular}

Source: Primary Data Analysis (2019)

Table 1 indicates that out of 50 Decision-Making Units (DMU) of tilapia farmers, only $12(24 \%)$ have achieved $100 \%$ efficiency or a value of 1 . The characteristics of DMU by age are presented in Table 2.

TABLE 2. EFFICIENCY DISTRIBUTION BASED ON AGE OF TILAPIA FARMERS IN WONOGIRI REGENCY IN 2019

\begin{tabular}{cccccc} 
Age & $\begin{array}{c}\text { Number of DMU } \\
\text { (Person) }\end{array}$ & $\begin{array}{c}\text { Number of DMU } \\
\text { Efficient I (Person) }\end{array}$ & $\begin{array}{c}\text { DMU Percentage } \\
(\%)\end{array}$ & $\begin{array}{c}\text { Efficient DMU } \\
\text { Percentage (\%) }\end{array}$ & $\begin{array}{c}\text { Efficient DMU Percentage } \\
(\%) \text { toward Age Range }\end{array}$ \\
\hline$<20$ & 0 & 0 & 0 & 0 & 0 \\
$20 \leq x<30$ & 5 & 0 & 10.00 & 0 & 0 \\
$30 \leq x<40$ & 16 & 5 & 32.00 & 10.00 & 31.25 \\
$40 \leq x<50$ & 24 & 7 & 48.00 & 14.00 & 29.17 \\
$50 \leq x<60$ & 4 & 0 & 8.00 & 0 & 0 \\
$\geq 60$ & 1 & 0 & 2.00 & 0 & 0 \\
\hline Total & 50 & 12 & 100.00 & 24.00 & 60.42 \\
\hline
\end{tabular}

Source: Primary Data Analysis (2019)

Table 2 shows that of the 50 tilapia farmer's DMUs with an efficiency value of 1 $(100 \%)$, twelve are in the age range of $30 \leq x<50$ years, indicating that the number of efficient DMUs is more than other ages. Tilapia farmers who have the highest efficiency value of $1(100 \%)$ are found in the age range of $40 \leq x<50$ years (14\%). At that age, tilapia farmers are in a productive period with more experience levels, higher enthusiasm in farming, a willingness to learn and seek information to achieve optimal results. While the characteristics of DMU based on the education level are displayed in the following table 3.

The table 3 shows that tilapia farmer DMUs have varying education levels from elementary school to postgraduate. Tilapia farmers with the highest efficiency of 1 (100\%) comprise 5 DMUs (10\%) at the elementary school level, 4 DMUs (8\%) at junior high school, 3 DMUs (6\%) at senior high school, and other levels of education. In short, there is no pattern that DMUs with higher education will have high efficiency due to the lack of lessons in agriculture or fishery in schools; not all schools provide lessons related to these two fields of knowledge. Willingness to continue to learn and more experience in farming can produce an optimal level of efficiency. 
TABLE 3.EFFICIENCY DISTRIBUTION BASED ON THE EDUCATION LEVEL OF TILAPIA FARMERS IN WONOGIRI REGENCY

\begin{tabular}{|c|c|c|c|c|}
\hline Education Level & $\begin{array}{l}\text { Number of DMU } \\
\text { (Person) }\end{array}$ & $\begin{array}{l}\text { Number of Efficient } \\
\text { DMU (Person) }\end{array}$ & DMU Percentage (\%) & $\begin{array}{l}\text { DMU Efficient } 1 \\
\text { Percentage (\%) }\end{array}$ \\
\hline $\begin{array}{l}\text { Not Completed Elementary } \\
\text { School }\end{array}$ & 0 & 0 & 0 & 0 \\
\hline Elementary School & 11 & 5 & 22 & 10 \\
\hline Junior High School & 10 & 4 & 20 & 8 \\
\hline Senior High School & 25 & 3 & 50 & 6 \\
\hline Undergraduate & 3 & 0 & 6 & 0 \\
\hline Postgraduate & 1 & 0 & 2 & 0 \\
\hline Total & 50 & 12 & 100 & 24 \\
\hline
\end{tabular}

Source: Primary Data Analysis (2019)

The characteristics of tilapia farmers in Wonogiri Regency are based on the use of seeds. All farmers have used the type of red tilapia. Based on the size, there are two types of tilapia seeds, the so-called kebul with seeds $5-7 \mathrm{~cm}$ in size and glondong sized 9-12 cm.

TABLE 4. EFFICIENCY DISTRIBUTION BASED ON SEED SIZE IN TILAPIA FARMING INWONOGIRI REGENCY

\begin{tabular}{ccccc}
\hline Seed Size & $\begin{array}{c}\text { Number of DMU } \\
\text { (Person) }\end{array}$ & $\begin{array}{c}\text { Number of Efficient } \\
\text { DMU (Person) }\end{array}$ & $\begin{array}{c}\text { DMU Percentage } \\
(\%)\end{array}$ & $\begin{array}{c}\text { Efficient DMU } \\
\text { Percentage (\%) }\end{array}$ \\
\hline $5-7 \mathrm{~cm}(\mathrm{kebul})$ & 30 & 12 & 60 & 24 \\
9-12 cm (glondong) & 20 & 0 & 40 & 0 \\
\hline DMU Total & 50 & 12 & 100 & 24 \\
\hline
\end{tabular}

Source: Primary Data Analysis (2019)

TABLE 5.DMU DISTRIBUTION BASED ON THE EFFICIENCY LEVEL OF TILAPIA WHOLESALERS IN WONOGIRI REGENCY

\begin{tabular}{ccc}
\hline Efficiency Value & Number of DMU (Person) & Percentage (\%) \\
\hline $0 \leq x<0.1$ & 0 & 0 \\
$0.1 \leq x<0.2$ & 0 & 0 \\
$0.2 \leq x<0.3$ & 0 & 0 \\
$0.3 \leq x<0.4$ & 0 & 0 \\
$0.4 \leq x<0.5$ & 0 & 0 \\
$0.5 \leq x<0.6$ & 0 & 0 \\
$0.6 \leq x<0.7$ & 0 & 0 \\
$0.7 \leq x<0.8$ & 0 & 0 \\
$0.8 \leq x<0.9$ & 0 & 0 \\
$0.9 \leq x<1.0$ & 1 & 16.67 \\
1 & 5 & 83.33 \\
\hline Total & 6 & 100.00
\end{tabular}

Source: Primary Data Analysis (2019)

Table 4 shows 12 DMU (24\%) achieving an efficiency value of 1 (100\%), with tilapia seeds sized $5-7 \mathrm{~cm}$ (white). Conversely, none of the DMUs using seeds sized $9-12 \mathrm{~cm}$ (glondong) obtains an efficiency value of $100 \%$. The use of seeds sized $5-7 \mathrm{~cm}$ (kebul) is more efficient as it is more adaptable to the floating net cage (KJA) environment in the Gajah Mungkur Reservoir, compared to tilapia seeds sized 9-12 cm (glondong). 
2. Analysis of the Efficiency of Tilapia Wholesalers in Wonogiri Regency

The performance measurement of tilapia wholesalers in Wonogiri Regency involved 6 DMUs directly related to tilapia farmers. Efficiency data from wholesalers are presented in Table 5.The efficiency calculations using the DEAP 2.1 program reveal that 5 DMUs (83.33\%) have an efficiency value of 1 (100\%), while 1 DMU (16.66\%) has an efficiency value of $0.9 \leq \mathrm{x}<1.0$. It implies that most of the wholesalers have been efficient.

TABLE 6. DMU DISTRIBUTION BASED ON THE EDUCATION LEVEL OF TILAPIA WHOLESALERS IN WONOGIRI REGENCY

\begin{tabular}{lcccc}
\hline Education Level & $\begin{array}{c}\text { Number of DMU } \\
\text { (Person) }\end{array}$ & $\begin{array}{c}\text { Number of DMU } \\
\text { Efficient I (Person) }\end{array}$ & DMU Percentage (\%) & $\begin{array}{c}\text { DMU Efficient l } \\
\text { Percentage (\%) }\end{array}$ \\
\hline $\begin{array}{l}\text { Not Completed Elementary } \\
\text { School }\end{array}$ & 0 & 0 & 0 & 0 \\
Elementary School & 1 & 1 & 16.67 & 16.67 \\
Junior High School & 0 & 0 & 0 & 0 \\
Senior High School & 5 & 4 & 83.33 & 66.67 \\
Higher Education & 0 & 0 & 0 & 0 \\
\hline \multicolumn{1}{c}{ Total } & 6 & 5 & 100.00 & 83.34 \\
\hline
\end{tabular}

Source: Primary Data Analysis (2019)

Table 6 shows that 5 DMUs (83.33\%) of tilapia wholesalers in Wonogiri Regency have a senior high school education, with four (66.67\%) obtain an efficiency level of 1 (100\%), and only one DMU ( 16.67\%) having elementary school education level, with an efficiency level of $1(100 \%)$. Based on education, there is no DMU pattern where higher education will have high efficiency. It reflects a willingness to continue to learn and work diligently, and experience in farming can produce an optimal efficiency level.

3. Analysis of the Efficiency of Tilapia Retailers in Wonogiri Regency

The performance measurement for tilapia retailers in Wonogiri Regency consists of 14 DMUs. Table 7 depicts the efficiency of data for retailers.

TABLE 7.DMU DISTRIBUTION BASED ON THE EFFICIENCY LEVEL OF TILAPIA RETAILERS IN WONOGIRI REGENCY

\begin{tabular}{|c|c|c|}
\hline Efficiency Value & Number of DMU (Person) & Percentage (\%) \\
\hline $0 \leq x<0.1$ & 0 & - \\
\hline $0.1 \leq x<0.2$ & 0 & - \\
\hline $0.2 \leq x<0.3$ & 0 & - \\
\hline $0.3 \leq x<0.4$ & 0 & - \\
\hline $0.4 \leq x<0.5$ & 0 & - \\
\hline $0.5 \leq x<0.6$ & 0 & - \\
\hline $0.6 \leq x<0.7$ & 0 & - \\
\hline $0.7 \leq x<0.8$ & 0 & - \\
\hline $0.8 \leq x<0.9$ & 0 & - \\
\hline $0.9 \leq x<1.0$ & 8 & 57.14 \\
\hline 1 & 6 & 42.86 \\
\hline Total & 14 & 100.00 \\
\hline
\end{tabular}

Source: Primary Data Analysis (2019)

The efficiency calculation data using the DEAP 2.1 program shows 6 DMUs (42.86\%) having an efficiency value of 1 (100\%) and 8 DMUs $(57.14 \%)$ with an efficiency value of $0.9 \leq \mathrm{x}<1.0$. The difference in efficiency between tilapia retailers is not too high, 
with an average efficiency value of 0.982 , indicating that the level of input and output uniformity between retailers is relatively the same.

TABLE 8. DMU CHARACTERISTIIS BASED ON THE EDUCATION LEVEL OF TILAPIA RETAILERS IN WONOGIRI REGENCY

\begin{tabular}{lcccc}
\hline $\begin{array}{c}\text { Education } \\
\text { Level }\end{array}$ & $\begin{array}{c}\text { Number of DMU } \\
\text { (Person) }\end{array}$ & $\begin{array}{c}\text { Number of DMU } \\
\text { Efficient I (Person) }\end{array}$ & DMU Percentage (\%) & $\begin{array}{c}\text { DMU Efficient I } \\
\text { Percentage (\%) }\end{array}$ \\
\hline Not Completed Elementary & 0 & 0 & - & - \\
School & 1 & 0 & 7.14 & - \\
Elementary School & 7 & 4 & 50.00 & 28.57 \\
Junior High School & 6 & 2 & 42.86 & 14.28 \\
Senior High School & 0 & 0 & - & - \\
Higher Education & 14 & 6 & 100.00 & 42.85 \\
\hline \multicolumn{1}{c}{ Total } & & & & \\
\hline
\end{tabular}

Source: Primary Data Analysis (2019)

Table 8 shows 7 retailer's DMUs (50\%) with junior high school education, 6 DMUs (42.86\%) having senior high school education, and only 1 DMU (7.14\%) with elementary school education. Of the 14 retailer's DMUs having an efficiency level of 1 (100\%), four (28.57\%) has an junior high school education, two (14.28\%) have a senior high school education, and none has a elementary school education.

4. Efficiency Analysis of Tilapia Supply Chain Actors in Wonogiri Regency

The efficiency calculation of tilapia supply chain actors based on the DEA method on 50 farmers shows the same results between 6 wholesalers and 14 retailers in Wonogiri Regency as presented in Table 9.

TABLE 9. DEA PROCESSING DATA ON THE EFFICIENCY OF TILAPIA SUPPLY CHAIN ACTORS

\begin{tabular}{lrrr}
\hline & \multicolumn{3}{c}{ Supply Chain Actors } \\
\cline { 2 - 4 } \multicolumn{1}{c}{ Description } & Tilapia Formers & Wholesalers & Retailers \\
\hline Number of DMU & 50 & 6 & 14 \\
Number of efficient DMU & 12 & 5 & 6 \\
The average value of efficiency & 0.789 & 0.998 & 0.982 \\
The minimum value of efficiency & 0.517 & 0.989 & 0.924 \\
The maximum value for efficiency & 1 & 1 & 1 \\
\hline Source: Primary Data Analysis (2019) & & &
\end{tabular}

Sari et al. (2014) stated that DEA can set targets to produce efficient performance and determine the value of input or output variables that must be increased or decreased to achieve the target value of potential improvement and attributes increased or decreased must be improved.

5. Analysis of Increasing the Efficiency of Tilapia Farmers in Wonogiri Regency

Calculations using the DEA method for 50 DMUs of tilapia farmers show that 12 (24\%) have an efficiency achievement of 1 (100\%). The DMU efficiency calculation for tilapia farmers in Wonogiri Regency varies widely from 0.517 to 1 , with an average efficiency level of 0.789, as shown in Table 10. It means that many DMUs need to evaluate their farming and look for causes of inefficiency. It is also a reference and shows the possibility of increasing output and improving the combination of input used by the DMUs to achieve 
efficiency. DMUs that have not reached efficiency are expected to learn from DMUs that have achieved efficiency to help their farming achieve efficiency levels. Setiawan et al. (2011) argue that the DEA calculation also provides information on potential improvement. Hence, each farmer (unit) can improve their performance. In more detail, data on DEA processing at the DMU of tilapia farmers are as follows:

TABLE 10. DEA PROCESSING DATA ON THE EFFICIENCY OF TILAPIA FARMERS IN WONOGIRI REGENCY IN 2019

\begin{tabular}{lr}
\hline \multicolumn{1}{c}{ Description } & Total \\
\hline Number of DMU & 50 \\
Number of efficient DMU & 12 \\
The average value of efficiency & 0.789 \\
The minimum value of efficiency & 0.517 \\
The maximum value for efficiency & 1 \\
Slack input average & \\
X1: Cost of seeds & $1,468,559.383$ \\
X2: Feed costs & $193,437.949$ \\
X3: Labor costs (outside the family labor) & $704,087.735$ \\
Slack Output Average & \\
Y1: Total production & 67.268 \\
Y2: Income & $2,851,911.946$ \\
\hline Saut
\end{tabular}

Source: Primary Data Analysis (2019)

Table 10 indicates that the performance between one tilapia farmer and others is very different. The performance efficiency values of actors range from $0.517(51.7 \%)$ to 1 (100\%). Moreover, the average efficiency value of tilapia farmers in Wonogiri Regency is 0.789. The Constant Return to Scale (CRS) calculation also looks at the slack of the input and output variables. Input slack or input access can be defined as how much input can be proportionally reduced to make the DMU efficient. The output slack is how much output can be increased proportionally to make the DMU at the most efficient point.

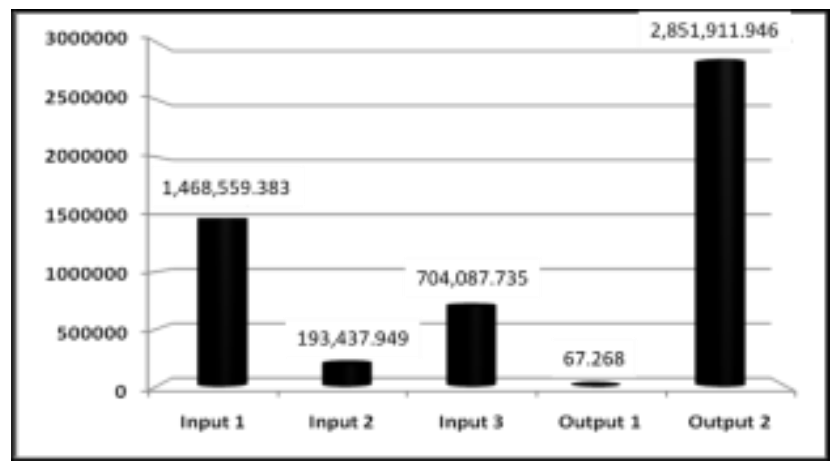

FIGURE 2. AVERAGE OF INPUT AND OUTPUT SLACKS OF TILAPIA FARMERS IN WONOGIRI REGENCY

Figure 2 explains that output 2 (income) is the highest slack output. It shows the potential for an increase in the average income of IDR 2,851,911,946 per farming period. The slack output that can be increased is output 1 (production), with an average increase of $67.268 \mathrm{~kg}$ per farming period. Meanwhile, the highest input slack or input access is found in input 1, namely the cost of seeds issued with an average cost of IDR 1,468,559,383 per period. It has the potential to be reduced without changing the amount of output to 
increase the efficiency value. The second input slack is in input 3, namely labor costs with an average of IDR 704,087,735 per period, potentially reduced without changing the resulting output, thereby achieving the efficiency value. The lowest input slack is the feed cost with an average of IDR 193,437,949, potentially reduced without changing the resulting output to achieve the efficiency value.

6. Analysis of Increasing Efficiency of Tilapia Supply Chain Performance by Wholesalers

The performance efficiency of the wholesaler's DMUs is 0.989 to 1 , with an average efficiency value of 0.998 , following the data in Table 10. It means that almost all of the wholesaler's DMUs are efficient. Of the 6 DMUs, only one is inefficient and needs improvements to increase output and enhance the combination of input used to achieve efficiency. The efficiency of the wholesaler's DMUs is as follows:

TABLE 11. DEA PROCESSING DATA ON THE EFFICIENCY OF TILAPIA WHOLESALERS IN WONOGIRI REGENCY IN 2019

\begin{tabular}{lr}
\hline \multicolumn{1}{c}{ Description } & Total \\
\hline Number of DMU & 6 \\
Number of efficient DMU & 5 \\
The average value of efficiency & 0.998 \\
The minimum value of efficiency & 0.989 \\
The maximum value for efficiency & 1 \\
Slack input average & \\
XI: Cost of purchasing the product IDR) & 0.00 \\
X2: Labor costs (IDR) & 0.00 \\
X3: Transport fee (IDR) & $276,845.638$ \\
Slack Output Average & \\
Y1: Total sales (Kg) & 10.798 \\
Y2: Income (IDR) & 0.000 \\
\hline Sade Patmat
\end{tabular}

Source: Primary Data Analysis (2019)

Table 11 reveals that the performance between one wholesaler and another is not too different. The efficiency values of wholesalers range from 0.989 (98.9\%) to 1 (100\%). Meanwhile, the average efficiency value of wholesalers was 0.998 (99.8\%). The Constant Return to Scale (CRS) calculation also looks at the slack of the input and output variables. Input or input excess can be defined as how much input can be reduced proportionally so that the DMU reaches the efficient point where the most efficient DMU is located. The slack output refers to how much output can be increased proportionally to make the DMU at the most efficient point (Coelli, 1996).

Figure 3 explains that input 3 (transportation costs) is the highest slack input or the highest input excess, with a value of IDR 276,845,638. It shows that the highest input can be reduced without changing the output amount to increase efficiency. In Input 1, the purchase cost of tilapia is 0 , meaning that the average purchase of the product has been efficient. Whereas in Input 2, the labor cost (sorting and loading and unloading) is 0 , meaning that the average labor cost is efficient. In output 1 , the number of sales can still increase by an average of $10.798 \mathrm{~kg} /$ month. Whereas in output 2 , the income is 0 , meaning that the average income of tilapia wholesalers in Wonogiri Regency is efficient. According to 
Chopra and Meindl (2007), effective supply chain management involves flowing products, information and funds to maximize supply chain profits.

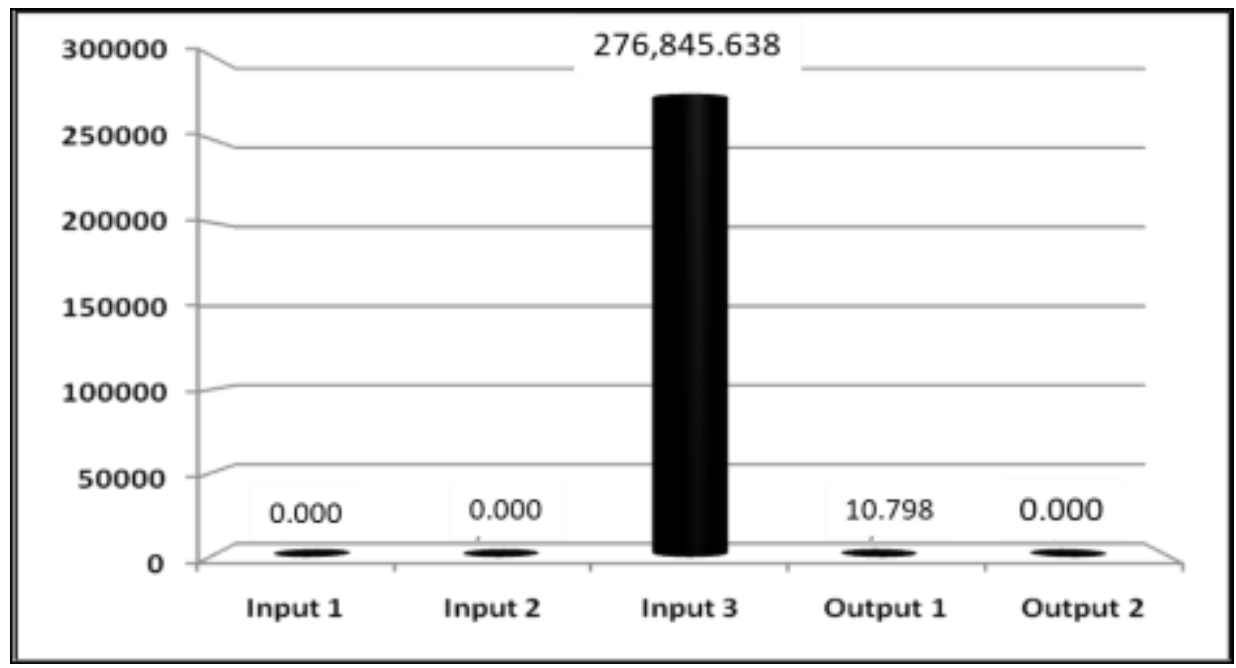

FIGURE 3. AVERAGE OF SLACK INPUTS AND SLACK OUTPUTS OF TILAPIA WHOLESALERS IN WONOGIRI REGENCY

7. Analysis of Increasing Efficiency of Tilapia Supply Chain by Retailers

The DMU efficiency values of the supply chain performance of tilapia retailers in Wonogiri Regency range from 0.924 to 1 . There are $8(57.14 \%)$ inefficient DMUs that should improve output and enhance the combination of input to achieve efficiency. The detailed results are presented in Table 12 .

TABLE 12. DEA PROCESSING DATA ON THE EFFICIENCY OF TILAPIA RETAILERS IN WONOGIRI REGENCY IN 2019

\begin{tabular}{lr}
\hline \multicolumn{1}{c}{ Description } & Total \\
\hline Number of DMU & 14 \\
Number of efficient DMU & 6 \\
The average value of efficiency & 0.982 \\
The minimum value of efficiency & 0.924 \\
The maximum value of efficiency & 1 \\
Slack input average & \\
X1: Purchase costs & $226,634.383$ \\
X2: Labor costs & $18,886.199$ \\
X3: Transport costs & $149,708.075$ \\
Slack Output Average & \\
Y1: Total sales & 0.000 \\
Y2: Income & 0.000 \\
\hline
\end{tabular}

Source: Primary Data Analysis (2019)

Table 12 shows that the performance between one retailer and other retailers is slightly different. The fluctuation value in the performance of the actors began with an efficiency value of $0.924(92.4 \%)$ to $1(100 \%)$. Input slack or input excess can be defined as how much input can be reduced proportionally so that the DMU reaches an efficient point.

Figure 4 explains that the input slack input 1, which is the cost of purchasing tilapia products from retailers, has the highest input slack or input excess value, namely IDR $226,634,383$, per month, potentially to be reduced to increase the efficiency value. It can be performed by reducing prices to buy tilapia. Furthermore, the second input slack is found in 
input 3, namely transportation costs, with an average of IDR $149,708,075$. It shows that transportation costs can still be reduced to increase the efficiency value of less efficient retailers. Reducing transportation costs can be conducted by reducing operational transportation costs through the use of cheaper and more efficient transportation fleets as well as using shorter road access. Reducing transportation costs can also be performed by increasing the purchase of tilapia products with an on-site delivery system. While the third input slack is found in input 2, namely labor costs (loading and unloading and sorting), with an average slack input of IDR $18,886,199$. It indicates that labor costs can be reduced to increase the efficiency value of retailers.

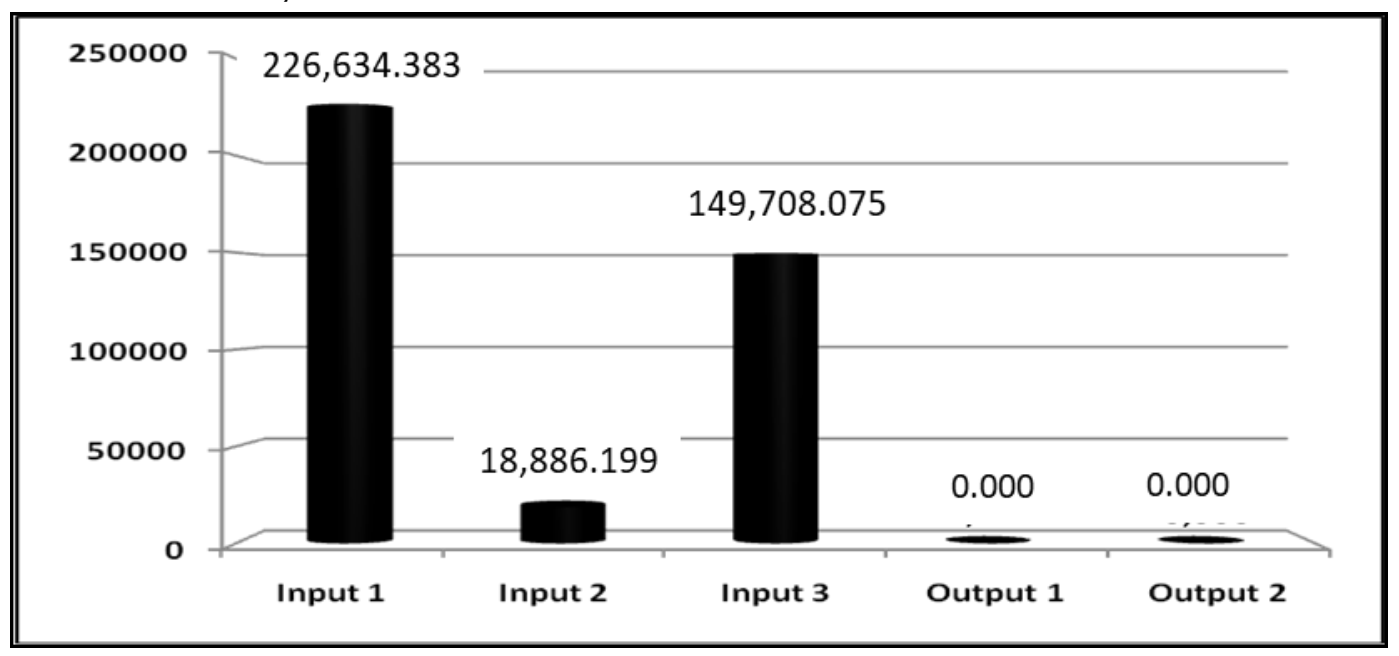

FIGURE 4. AVERAGE SLACK INPUTS OF TILAPIA RETAILERS IN WONOGIRI REGENCY IN 2019

\section{CONCLUSIONS}

The following conclusions were drawn based on the analysis results and research objectives:

1. The supply chain mechanism of tilapia farming in Wonogiri Regency consisted of several levels of actors, from farmers, wholesalers and retailers.

2. Some tilapia farmers chose to sell their products to wholesalers $(35.71 \%)$ and retailers (64.29\%), and none sold their products directly to consumers.

3. Based on performance measurement using the DEA method on actors in the supply chain of tilapia farming in Wonogiri Regency, the most efficient actors were wholesalers for having an average efficiency value of 0.998. It means that, on average, it has approached the value of 1 (efficient). Meanwhile, the most inefficient actors were tilapia farmers with an average efficiency value of 0.789 . Of the 50 DMUs of tilapia farmers, only 12 (24\%) were efficient, while the remaining 38 DMUs (76\%) should be improved to achieve the expected efficiency. Hence, farmers are actors in the supply chain of tilapia in Wonogiri Regency, requiring special attention.

4. The analysis results using the DEA method showed that $83.33 \%$ of wholesaler's DMUs were declared efficient and $16.67 \%$ inefficient, while $42.86 \%$ of retailer's DMUs received an efficient value of 1 (100\%), and the remaining $57.14 \%$ were inefficient. 
5. Inefficient DMUs should be improved by imitating efficient DMUs to increase output or improve input combinations to achieve efficiency. Of 50 tilapia farmer's DMUs, 38 (76\%) required improvements to achieve efficiency. Furthermore, one (16.67\%) from 6 wholesaler's DMUs required some improvements. Meanwhile, of 14 retailer's DMU, 8 (57.14\%) also required improvements to achieve efficiency.

\section{REFERENCES}

Central Statistics Agency (Badan Pusat Statistik Nasional). (2020). Laju Pertumbuhan Komulatif PDB Menurut Lapangan Usaha (Persen) 2016-2019. Jakarta: BPS. https://www.bps.go.id/dynamictable/2017/05/05/1253/-seri-2010-lajupertumbuhan-kumulatif-produk-domestik-bruto-menurut-lapangan-usaha-persen2017--2019.html

Central Java of Central Statistics Agency (Badan Pusat Statistik Provinsi Jawa Tengah). (2018). Produksi Perikanan Budidaya Menurut Kabupaten/Kota dan Subsektor di Provinsi Jawa Tengah. Semarang: BPS Jawa Tengah. https://jateng.bps.go.id/statictable/2017/10/27/1551/produksi-perikananbudidaya-menurut-kabupaten-kota-dan-subsektor-di-provinsi-jawa-tengah-ton2016.html

Coelli T. J., (1996), A Guide to DEAP Version 2.1: A Data Envelopment Analysis (DEA) (computer) Program" CEPA Working Papers, Australia:.Department Of Economics University Of New England.

Chopra S, Meindehl P. (2007). Supply Chain Management: Strategy, Planning, and Operation. New Jersey: Pearson Prentice Hall.

Dinas Kelautan dan Perikanan Provinsi Jawa Tengah. (2017). Perikanan Budidaya Jawa Tengah Dalam Angka Tahun 2016. Semarang: DKP Prov. Jawa Tengah.

Dirjen Penguatan Daya Saing Produk Kelautan dan Perikanan. (2018). Produtifitas Perikanan Indonesia. Jakarta: KKP. https://kkp.go.id/wpcontent/uploads/2018/01/KKP-Dirjen-PDSPKP-FMB-Kominfo-19-Januari-2018.pdf

Indrajit RE, dan Djokopranoto. R. (2002). Konsep Manajemen Supply Chain. Cara Baru Memandang Mata Rantai Penyediaan Barang. Jakarta: Grasindo.

Janvier-James AM. (2012). A new Introduction to Supply Chains and Supply Chain Management: Definitions and Theories Perspective. International Bussiness Research Journal5 (1): pp194-207. http://dx.doi.org/10.5539/ibr.v5n1p194

Kohar dan Wibowo. (2015). Dampak Pengembangan Perikanan Budidaya terhadap Penurunan Kemiskinan,Peningkatan Pendapatan dan Penyerapan Tenaga Kerja di Jawa Tengah. Semarang: Undip. http://eprints.undip.ac.id/35266/1/MakalahKohar-Argo-JKT22Sept-11.pdf

Nazir, Moh. (2014). Metode Penelitian Cet.9. Bogor: Ghalia Indonesia.

Pujawan I.N. (2005). Supply Chain Management. Surabaya: Guna Widya. 
Sari SW. Nurmalina R. Setiawan B. (2014). Efisiensi Kinerja Rantai Pasok Ikan Lele di Indramayu, Jawa Barat. Jurnal Manajemen dan Agribisnis. 11(1). https://doi.org/10.17358/jma.11.1.12-23

Setiadi, et al.(2018). Analisis Kinerja Rantai Pasok Ikan Nila Pada Bandar Sriandoyo di Kecamatan Tugumolyo Kabupaten Musi Rawas. Jurnal Ilmiah Manajemen Vol.VIII. http://dx.doi.org/10.22441/mix.2018.v8i1.010

Setiawan, et al.(2011). Studi Peningkatan Kinerja Manajemen Rantai Pasok Sayuran Dataran Tinggi di Jawa Barat. Agritect Vol.31. https://doi.org/10.22146/agritech.9727

Surakhmad W. (1994). Pengantar Penelitian Ilmiah. Bandung: Tarsito.

Suratna, dan Lincolin Arsyad. (1995). Metodologi Penelitian untuk Ekonomi dan Bisnis. Yogyakarta: UUP YKPN.

Trienekens JH. 2011. Agricultural Value Chains In Developing Countries: A Framework For Analysis. Journal of International Food and Agribusiness Management Review14 (2):1-82. https://doi.org/10.22004/AG.ECON.103987

Vorst VD, J.G.A.D. (2004). Supply Chain Management: Theory and Practices. The Emerging World of Chains \& Networks, Elsevier, Hoofd-stuk 2.1. Wegeningen https://www.researchgate.net/publication/40122004

Zhou P, Ang BW, Poh KL. (2008). Measuring Environmental Performance Under Different Environmental DEA Technologies. Journal Technology Economics. 30(1), https://doi.org/10.1016/j.eneco.2006.05.001 